\title{
The Analysis of Academic Motivation and Career Stress Relationships of the Students in Department of Physical Education and Sport
}

\author{
Turan Çetinkaya ${ }^{1}$ \\ ${ }^{1}$ School of Physical Education and Sports, Ahi Evran University, Kırşehir, Turkey \\ Correspondence: Turan Çetinkaya, School of Physical Education and Sport, Ahi Evran University, Kırşehir, \\ Turkey.
}

Received: November 15, 2018

doi:10.5539/ies.v12n4p24

\author{
Accepted: December 28, $2018 \quad$ Online Published: March 10, 2019 \\ URL: https://doi.org/10.5539/ies.v12n4p24
}

\begin{abstract}
The purpose of this study is to determine the levels of career stress and academic motivation of the students in the departments of physical education and sports. 527 students who receive education in Physical Education and Sports Academies of Ahi Evran University, Erciyes University, Dumlupınar University and Çanakkale 18 Mart University participated in the study. In this study, personal information form, career stress scale and academic motivation scale were used as data collection tools. In the comparison of relevant data, range, frequency, $t$ test, Anova test and simple regression analysis were performed. Besides, Confirmatory Factor Analysis (CFA) was performed in order to reveal the factor structures of academic motivation and career stress scales. As a result of statistical analyzes, significant difference was not seen at levels of academic motivation and career stress for all dimensions in terms of the gender and certified sportsmanship variables of the participants. However, significant difference was seen in the total scores of identified extrinsic motivation, extrinsic motivation extrinsic regulation, career uncertainty, job finding pressure and career stress in terms of grade variable. According to the results of the regression analyzes performed, negative significant correlation was detected between the academic motivation and career stress levels of participants.
\end{abstract}

Keywords: academic motivation, career stress, student athlete

\section{Introduction}

Motivation is defined as "the processes within an individual that stimulate behavior and channel it into the ways that should be benefited by the whole organization" (Lunenburg \& Ornstein, 2011). This motive is realized for satisfying the basic needs (Bursalığlu, 1999). Wolters (2004) defines being motivated as the tendency to do an act in any way, and motivation as a specific need or desire that causes this tendency. Rivers (1983) defines motivation as obtaining something about the inner world of the organism, being able to discuss and research about it, and also emphasizes the abstract aspect of motivation. Dörnyei and Ottó (1998) develop a new approach and emphasize some terms like energy and driving force and at the same time they draw attention to the changing model of the concept of motivation. Pintrich and Schunk (2002) state motivation as "the process in which directly goal-oriented activity is started and sustained". Motivation "is an intrinsic situation, which reveals, directs, and provides the behavior to be persistent" (Woolfolk, 2004).

Academic motivation based on the self-determination theory developed by Deci and Ryan (2000a). Intrinsic motivation which is developed according to the self -determination theory, extrinsic motivation and amotivation includes the factors, which put individual into action against a situation. Intrinsic motivation is related with the enjoyment and the desire to perform action that is found interesting by individual (Deci \& Ryan, 2000b). "Extrinsic motivation is related with the enjoyment, which would be given by the results of actions performed. It is the power that emerges in result-oriented activities and focuses to benefit from the action unlike the intrinsic motivation. According to the researches, there are a lot of factors that affect the success of student. For example, according to Karagüven (2012) these are factors like effectively leading himself/herself of student, planning and monitoring skills, and evaluating his/her own behaviors, apprehension and learning strategies. Also, the student should be motivated to use new learning strategies effectively at the same time. Though the term motivation is an umbrella term and includes series of motives, its effect on the behavior is very clear and worth examining. Although they have remarkable skills, appropriate education program and good teachers, individuals can't achieve their long-term goals without having enough motivation (Dörnyei, 1998). 
Stress is a term, which has effects on individuals and influences their behavior, productivity, and relationships with other people. Stress does not come into existence for no reason by itself. For the stress to come into existence, the changes, which occur in the atmosphere or environment that the person lives in, are required to affect the person (Eren, 2001). There is a correlation between the organism and the environment. Stress emerges when there is an imbalance between the demands of the environment and the organism's coping mechanisms (McGrath, 1970).

Feeling inadequate for some specific decisions, not knowing themselves enough and having difficulties in determining suitable goals for themselves are among the problems that the college students face in our country regarding their career development (Işık, 2010). The difficulties that students faced about their career process also affect the psychological well-being of students (Özden \& Sertel-Berk, 2016). Also, the students generally encounter many sources of stress related to the academic subjects, financial concerns, social relations and career process during the university years. However, the students gave the career-related subjects to be stated as the first priority among all these sources of stress. Thus, the university years are an important process for students to set goals for the time after graduation and creating a career plan. But many of the college students having difficulties about their career plan and it is seen that a considerable part of these students' level of psychological discommodity (anxiety, depression) is higher than the general population and their level of psychological well-being is low (Fouad et al., 2006, Kim, 2003).

Gottfried (1990) states that having higher academic motivation is related with having higher perception of competence, and by contrast, it is related with having low-level of anxiety. Academic motivation and career perception are two factors that affect students during their university years. From this point of view, revealing the academic motivation and career stress relations of students who receive education in department of physical education and sport is targeted in this study.

\section{Method}

\subsection{Target Population and Sample}

In the model of the research, a method for descriptive screening was followed. The research consists of two stages. In the first phase of the study, available information is given systematically by scanning the relevant literature. Thus, a theoretical structure has been formed on the subject. In the second phase of the research, the questionnaires developed in order to reach the aim were applied to the sample group. The population of this study consisted of students who receive education in School of Physical Education and Sports of Ahi Evran University, Erciyes University, Dumlupınar University and Çanakkale 18 Mart University during the 2018-2019 academic period. The research sample was represented by 527 students.

\subsection{Data Collection Tools}

Personal Information Form, Academic Motivation Scale (AMS) and Career Stress Scale (CSS) were used as data collection tools in the study.

\section{Academic Motivation Scale (AMS):}

Academic Motivation Scale which was developed by Vallerand (1992) and of which validity and reliability study was made by Karagüven (2012), consists of 28 articles and 7 sub-dimensions. These sub-dimensions are intrinsic motivation to know (IM-to know), intrinsic motivation towards accomplishments (IM-to accomplish things), intrinsic motivation to experience stimulation (IM-to experience stimulation), identified extrinsic motivation (IEM), introjected extrinsic motivation (IntEM), Extrinsic motivation-external regulation (EM-ER) and amotivation (AM). The measuring instrument is a 7-point Likert type scale ranges from 1 (strongly disagree) to 7 (strongly agree). Statements in the dimension of amotivation are reverse in comparison to the others. But these articles are scored like the others when scoring. So, there was no item scored reversely in the scale. Calculated Cronbach Alpha coefficient for the total reliability of the scale was 0.87 and it varies between 0.67 and 0.87 for sub-dimensions (Karagüven, 2012). The Cronbach Alpha value for this study is calculated as 0,866. Cronbach Alpha values for sub-dimensions are (0.925) for intrinsic motivation to know, $(0.856)$ for intrinsic motivation towards accomplishments, $(0.849)$ for intrinsic motivation to experience stimulation, $(0.934)$ for identified extrinsic motivation, $(0.828)$ for introjected extrinsic motivation, (0.849) for extrinsic motivation-external regulation and (0.888) for amotivation.

Confirmatory Factor Analysis (CFA) was conducted for validation of the structure of scale which consisted of 28 articles and 7 sub-dimensions. CFA is a process to create implicit variables based on the variables which are observed via a model created in advance (Schumarker \& Lomax, 1996). 
Table 1. Model data fit values in relation to academic motivation scale (standardized solution)

\begin{tabular}{lcccccc}
\hline & $\chi^{2}(\mathrm{sd})$ & RMSEA & GFI & AGFI & CFI & NNFI \\
\hline $\begin{array}{l}\text { First-Stage One-Factor } \\
\text { Rob.6 }\end{array}$ & 0.040 & 0.92 & 0.91 & 0.99 & 0.99 \\
\hline
\end{tabular}

When the Table 2 is examined it is understood that $\chi^{2}$ value is $606.6, \mathrm{df}=329 \mathrm{p}=0.00, \chi^{2} / \mathrm{sd}=1.84$. Perfect fit was observed when REMSEA, AGFI, GFI, CFI and NNFI values are compared to the critical values.

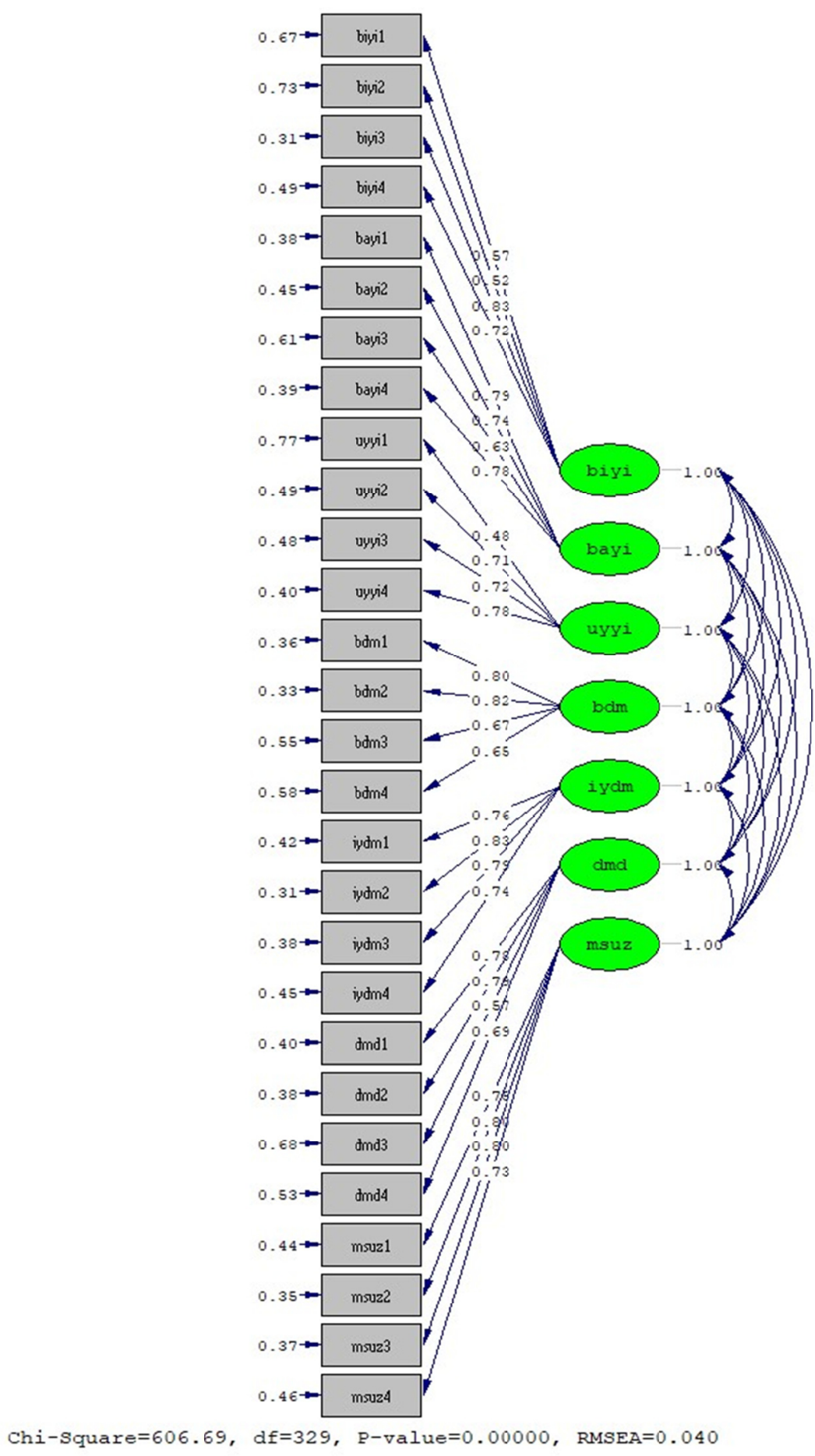

Figure 1. Belongs to CFA analysis of Academic Motivation Scale 


\section{Career Stress Scale (CSS):}

Career Stress Scale (CSS), which was developed by Choi et al. (2011) and of which Turkish validity and reliability study was made by Özden and Sertel-Berk (2017), consist of totally 20 articles and 3 sub-dimensions, which are career uncertainty (cu), job finding pressure (jfp), and extrinsic conflict (ec). Measurement instrument was scored between strongly disagree (1) and strongly agree (5). The lowest score that could be obtained from the scale was 20 and the highest was 100. Obtaining high score refers to the high level of career stress. In the original study, Cronbach Alpha coefficients calculated for internal consistency reliability, were founded as .89 for career uncertainty, .85 for job finding pressure and .83 for extrinsic conflict. In this study, on the other hand, Cronbach Alpha coefficients calculated for internal consistency reliability were founded as .949 for total score, .928 for career uncertainty, .860 for job finding pressure and .766 for extrinsic conflict.

Confirmatory Factor Analysis (CFA) was conducted for validation of the structure of scale which is consisted of 20 articles and 3 sub-dimensions. CFA is a process to create implicit variables based upon variables that are observed via a model which was created in advance (Schumarker \& Lomax, 1996).

Table 2. Model data fit values for career stress scale (standardized solution)

\begin{tabular}{lcccccc}
\hline & $\chi^{2}(\mathrm{sd})$ & RMSEA & GFI & AGFI & CFI & NNFI \\
\hline $\begin{array}{l}\text { First-Stage One-Factor } \\
\begin{array}{r}516.89 \\
\text { Robust ML }\end{array}\end{array}$ & 0.063 & 0.91 & 0.89 & 0.99 & 0.98 \\
\hline
\end{tabular}

When the Table 1 is examined it is understood that $\chi 2$ value is $516.89, \mathrm{df}=167 \mathrm{p}=0.00, \chi 2 / \mathrm{sd}=3.09$. When REMSEA and AGFI values are compared to the critical values, acceptable fit was observed, when GFI, CFI and NNFI values, on the other hand compared to the critical values perfect fit was observed.

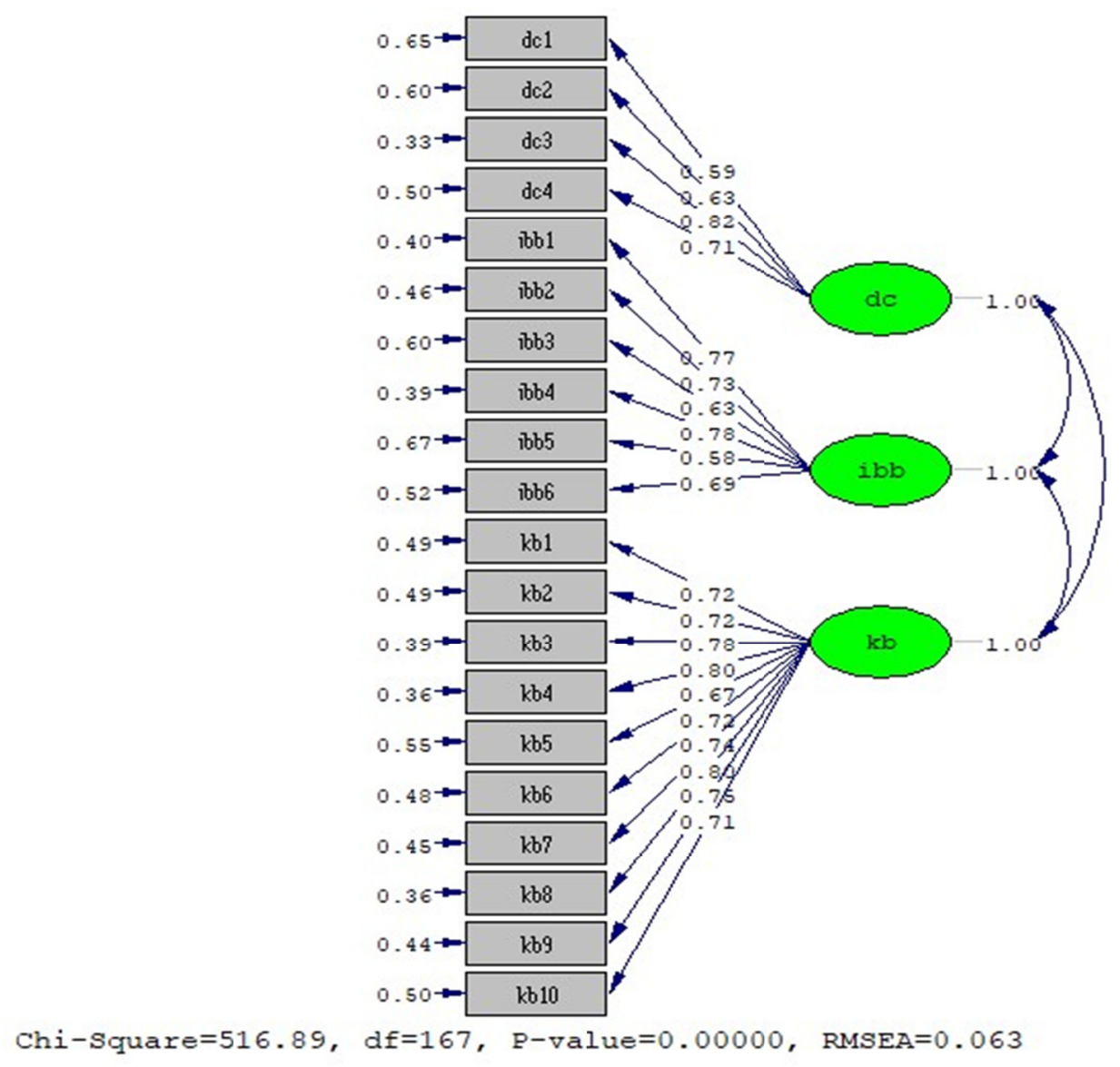

Figure 2. Represents the CFA analysis of career stress scale 


\subsection{Data Collection}

Questionnaires, which were used in the study, were applied to the students who studied in Ahi Evran University, Erciyes University, Dumlupınar University and Çanakkale 18 Mart University Schools of Physical Education and Sports in between 2017/2018 academic year. Essential explanations about the purpose of the study were made to the participants who take part in the study and detailed information was given about how to fill in the data collection tool in advance. Data collection tool that was collected by the researcher was checked and incomplete or incorrect ones were excluded. And then, data collection forms, which are valid and acceptable (527 pieces), were transferred to the electronic media by being coded in order to be evaluated.

\subsection{Data Analysis}

Data analysis of which collected during the research was executed on SPSS 20.0 statistics packaged software. Distribution, frequency, $t$ test, Anova test and regression analysis were conducted for the evaluation of the data. In the tests made for the data analysis; equality of variances principle that is from the premises of parametric tests was based and, in cases of variances' inequality, even " $p$ " value is smaller than the significance level, a significance difference was not searched for between groups. Significance level was determined as $\alpha=0.05$ in analyzes.

\section{Findings}

Table 3. Distribution of academic motivation and career stress total scores and their sub-dimensions for all participants

\begin{tabular}{llll}
\hline Dimensions & $\mathrm{N}$ & Mean & $\mathrm{sd}$ \\
\hline Intrinsic Motivation to Know & 527 & 5.14 & 1.71 \\
Intrinsic Motivation Towards Accomplishments & 527 & 4.50 & 1.56 \\
Intrinsic Motivation to Experience Stimulation & 527 & 4.39 & 1.59 \\
Identified Extrinsic Motivation & 527 & 5.24 & 1.75 \\
Introjected Extrinsic Motivation & 527 & 4.32 & 1.65 \\
Extrinsic Motivation-External Regulation & 527 & 5.21 & 1.68 \\
Amotivation & 527 & 2.88 & 1.80 \\
Academic Motivation Total & 527 & 4.53 & 1.34 \\
Career Uncertainty & 527 & 2.59 & 1.13 \\
Job Finding Pressure & 527 & 2.93 & 1.04 \\
Extrinsic Conflict & 527 & 2.57 & 1.18 \\
Career Stress Total & 527 & 2.69 & 1.04 \\
\hline
\end{tabular}

For the research participants' total scores, which they obtained from the Academic Motivation scale, the arithmetic mean was 4.53 and the standard deviation was 1.34 . For the scores that they obtained from Career stress scale, the arithmetic mean was 2.69 and the standard deviation was 1.04 . 
Table 4. Frequency and percentage distributions towards demographic information of the participants

\begin{tabular}{lccc}
\hline Variables & Sub-variables & F & $\%$ \\
\hline \multirow{3}{*}{ Gender } & Male & 319 & 60.5 \\
& Female & 208 & 39.5 \\
& 1 & 123 & 23.3 \\
Grade & 2 & 131 & 24.9 \\
& 3 & 169 & 32.1 \\
& 4 & 96 & 18.2 \\
& $5+$ & 8 & 1.5 \\
University & Ahi Evran & 179 & 34.0 \\
& Dumlupınar & 100 & 19.0 \\
& Erciyes & 127 & 24.1 \\
Licensed Sports & Çanakkale & 121 & 23.0 \\
Total & Yes & 314 & 59.6 \\
& No & 213 & 40.4 \\
& 527 & 527 & 100 \\
\hline
\end{tabular}

319 of the students who participated in the research are male and 208 of them are female. 123 of the participants are in the $1^{\text {st }}$ grade, 131 of them are in $2^{\text {nd }}$ grade, 169 of them are in $3^{\text {rd }}$ grade, 96 of them are in $4^{\text {th }}$ grade and 8 of them extended the school. 179 students from Ahi Evran University, 100 students from Dumlupinar University, 127 students from Erciyes University and 121 students from Çanakkale 18 Mart University took part in the study group. 314 of the students are certified sportsman and 213 of them are not certified.

Table 5. T-Test results of comparing academic motivation and career stress total scores and their sub-dimensions according to gender of the participants

\begin{tabular}{|c|c|c|c|c|c|c|}
\hline Dimensions & Gender & $\mathrm{n}$ & $\mathrm{X}$ & $\mathrm{Sd}$ & $\mathrm{t}$ & $\mathrm{P}$ \\
\hline \multirow{2}{*}{ IM to know } & Male & 319 & 5.19 & 1.67 & \multirow{2}{*}{.720} & \multirow{2}{*}{.472} \\
\hline & Female & 208 & 5.08 & 1.76 & & \\
\hline \multirow{2}{*}{ IM to accomplish things } & Male & 319 & 4.57 & 1.55 & \multirow{2}{*}{1.322} & \multirow{2}{*}{.187} \\
\hline & Female & 208 & 4.39 & 1.57 & & \\
\hline \multirow{2}{*}{ IM to experience stimulation } & Male & 319 & 4.43 & 1.57 & \multirow{2}{*}{.696} & \multirow{2}{*}{.487} \\
\hline & Female & 208 & 4.33 & 1.62 & & \\
\hline \multirow{2}{*}{ IEM } & Male & 319 & 5.24 & 1.71 & \multirow{2}{*}{-.035} & \multirow{2}{*}{.972} \\
\hline & Female & 208 & 5.25 & 1.80 & & \\
\hline \multirow{2}{*}{ IntEM } & Male & 319 & 4.37 & 1.63 & \multirow{2}{*}{.789} & \multirow{2}{*}{.431} \\
\hline & Female & 208 & 4.25 & 1.67 & & \\
\hline \multirow{2}{*}{ EM-ER } & Male & 319 & 5.29 & 1.65 & \multirow{2}{*}{1.290} & \multirow{2}{*}{.198} \\
\hline & Female & 208 & 5.10 & 1.73 & & \\
\hline \multirow{2}{*}{ Amotivation } & Male & 319 & 2.87 & 1.81 & \multirow{2}{*}{-.179} & \multirow{2}{*}{.858} \\
\hline & Female & 208 & 2.90 & 1.80 & & \\
\hline \multirow{2}{*}{ Academic Motivation Toplam } & Male & 319 & 4.57 & 1.32 & & \multirow{2}{*}{.428} \\
\hline & Female & 208 & 4.47 & 1.37 & .794 & \\
\hline \multirow{2}{*}{$\mathrm{Cu}$} & Male & 319 & 2.61 & 1.13 & \multirow{2}{*}{.361} & \multirow{2}{*}{.718} \\
\hline & Female & 208 & 2.57 & 1.12 & & \\
\hline \multirow{2}{*}{ Jfp } & Male & 319 & 2.91 & 1.03 & \multirow{2}{*}{-.577} & \multirow{2}{*}{.564} \\
\hline & Female & 208 & 2.96 & 1.06 & & \\
\hline \multirow{2}{*}{ Ec } & Male & 319 & 2.58 & 1.17 & \multirow{2}{*}{.299} & \multirow{2}{*}{.765} \\
\hline & Female & 208 & 2.55 & 1.21 & & \\
\hline Career Stress Total & Male & 319 & 2.69 & 1.04 & 001 & 027 \\
\hline Career Stress lotal & Female & 208 & 2.68 & 1.05 & . & \\
\hline
\end{tabular}

$* \mathrm{p}>0.05$.

When the participants' academic motivation and career stress total scores are examined in terms of gender variable, there is no significant difference. While mean of males are 4.57 , mean of females are 4.47 for academic 
motivation scale. And for the career stress scale, on the other hand, while mean of males are 2.69, mean of females are 2.68. When sub-dimensions are examined for both scales, there is no difference in all sub-dimensions.

Table 6. T-Test results of comparing academic motivation and career stress total scores and their sub-dimensions according to certified sportsmanship variable of the participants

\begin{tabular}{|c|c|c|c|c|c|c|}
\hline Dimensions & $\begin{array}{c}\text { Certified } \\
\text { Sportsmanship }\end{array}$ & $\mathrm{N}$ & $X$ & ss & $\mathrm{t}$ & $\mathrm{P}$ \\
\hline \multirow{2}{*}{ IM to know } & Yes & 314 & 5.12 & 1.71 & \multirow{2}{*}{-.475} & \multirow{2}{*}{.635} \\
\hline & No & 213 & 5.19 & 1.70 & & \\
\hline \multirow{2}{*}{ IM to accomplish things } & Yes & 314 & 4.46 & 1.58 & \multirow{2}{*}{-.598} & \multirow{2}{*}{.550} \\
\hline & No & 213 & 4.55 & 1.54 & & \\
\hline \multirow{2}{*}{ IM to experience stimulation } & Yes & 314 & 4.38 & 1.59 & \multirow{2}{*}{-.172} & \multirow{2}{*}{.864} \\
\hline & No & 213 & 4.40 & 1.58 & & \\
\hline \multirow{2}{*}{ IEM } & Yes & 314 & 5.27 & 1.75 & \multirow{2}{*}{.420} & \multirow{2}{*}{.675} \\
\hline & No & 213 & 5.21 & 1.75 & & \\
\hline \multirow{2}{*}{ IntEM } & Yes & 314 & 4.33 & 1.67 & \multirow{2}{*}{.109} & \multirow{2}{*}{.914} \\
\hline & No & 213 & 4.31 & 1.62 & & \\
\hline \multirow{2}{*}{ EM-ER } & Yes & 314 & 5.22 & 1.69 & \multirow{2}{*}{.052} & \multirow{2}{*}{.959} \\
\hline & No & 213 & 5.21 & 1.67 & & \\
\hline \multirow{2}{*}{ Amotivation } & Yes & 314 & 2.91 & 1.81 & \multirow{2}{*}{.334} & \multirow{2}{*}{.738} \\
\hline & No & 213 & 2.85 & 1.79 & & \\
\hline \multirow{2}{*}{ Akademic Motivation Total } & Yes & 314 & 4.53 & 1.35 & \multirow{2}{*}{-.044} & \multirow{2}{*}{.965} \\
\hline & No & 213 & 4.53 & 1.33 & & \\
\hline \multirow{2}{*}{$\mathrm{Cu}$} & Yes & 314 & 2.61 & 1.14 & \multirow{2}{*}{.389} & \multirow{2}{*}{.698} \\
\hline & No & 213 & 2.57 & 1.12 & & \\
\hline \multirow{2}{*}{ Jfp } & Yes & 314 & 2.97 & 1.05 & \multirow{2}{*}{.973} & \multirow{2}{*}{.331} \\
\hline & No & 213 & 2.88 & 1.02 & & \\
\hline \multirow{2}{*}{ Ec } & Yes & 314 & 2.59 & 1.20 & \multirow{2}{*}{.493} & 622 \\
\hline & No & 213 & 2.54 & 1.17 & & .022 \\
\hline Career Stress Total & Yes & 314 & 2.71 & 1.05 & 615 & 539 \\
\hline 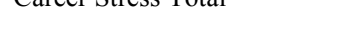 & No & 213 & 2.65 & 1.03 & . 010 & \\
\hline
\end{tabular}

When the participants' academic motivation and career stress total scores are examined in terms of certified sportsmanship variable, there is no significant difference. While mean of certified sportsman are 4.53, mean of students who are not certified sportsman, are 4.53 for the academic motivation scale. And for the career stress scale, on the other hand, while mean of certified sportsman are 2.71, mean of students who are not certified sportsman are 2.65. When sub-dimensions are examined, there is no difference in all sub-dimensions for both scales. 
Table 7. Anova test results of comparing academic motivation and their sub-dimensions scores according to grade variable of the participants

\begin{tabular}{|c|c|c|c|c|c|c|c|}
\hline Dimensions & Grade & $\mathrm{n}$ & Mean & $\mathrm{Sd}$ & $\mathrm{f}$ & $\mathrm{P}$ & $\begin{array}{l}\text { Significant } \\
\text { Difference }\end{array}$ \\
\hline \multirow{5}{*}{ IM to know } & $1^{\text {st }}$ grade & 123 & 5.43 & 1.44 & \multirow{5}{*}{2.393} & \multirow{5}{*}{.050} & \multirow{5}{*}{----} \\
\hline & $2^{\text {nd }}$ grade & 131 & 4.88 & 1.80 & & & \\
\hline & $3^{\text {rd }}$ grade & 169 & 5.27 & 1.64 & & & \\
\hline & $4^{\text {th }}$ grade & 96 & 4.91 & 1.90 & & & \\
\hline & $5+$ & 8 & 5.18 & 2.18 & & & \\
\hline \multirow{5}{*}{ IM to accomplish things } & $1^{\text {st }}$ grade & 123 & 4.69 & 1.32 & \multirow{5}{*}{1.213} & \multirow{5}{*}{.304} & \multirow{5}{*}{---- } \\
\hline & $2^{\text {nd }}$ grade & 131 & 4.33 & 1.69 & & & \\
\hline & $3^{\text {rd }}$ grade & 169 & 4.58 & 1.53 & & & \\
\hline & $4^{\text {th }}$ grade & 96 & 4.34 & 1.68 & & & \\
\hline & $5+$ & 8 & 4.31 & 1.78 & & & \\
\hline \multirow{5}{*}{ IM to experience stimulation } & $1^{\text {st }}$ grade & 123 & 4.61 & 1.41 & \multirow{5}{*}{1.456} & \multirow{5}{*}{.214} & \multirow{5}{*}{---- } \\
\hline & $2^{\text {nd }}$ grade & 131 & 4.15 & 1.64 & & & \\
\hline & $3^{\text {rd }}$ grade & 169 & 4.44 & 1.57 & & & \\
\hline & $4^{\text {th }}$ grade & 96 & 4.35 & 1.75 & & & \\
\hline & $5+$ & 8 & 4.25 & 1.52 & & & \\
\hline \multirow{5}{*}{ IEM } & $1^{\text {st }}$ grade & 123 & 5.64 & 1.46 & \multirow{5}{*}{2.885} & \multirow{5}{*}{.022} & \multirow{5}{*}{$1-2$} \\
\hline & $2^{\text {nd }}$ grade & 131 & 4.98 & 1.78 & & & \\
\hline & $3^{\text {rd }}$ grade & 169 & 5.30 & 1.76 & & & \\
\hline & $4^{\text {th }}$ grade & 96 & 5.02 & 1.92 & & & \\
\hline & $5+$ & 8 & 4.93 & 2.02 & & & \\
\hline \multirow{5}{*}{ IntEM } & $1^{\text {st }}$ grade & 123 & 4.50 & 1.51 & \multirow{5}{*}{1.491} & \multirow{5}{*}{.204} & \multirow{5}{*}{---- } \\
\hline & $2^{\text {nd }}$ grade & 131 & 4.07 & 1.78 & & & \\
\hline & $3^{\text {rd }}$ grade & 169 & 4.45 & 1.56 & & & \\
\hline & $4^{\text {th }}$ grade & 96 & 4.21 & 1.75 & & & \\
\hline & $5+$ & 8 & 4.43 & 1.71 & & & \\
\hline \multirow{5}{*}{ EM-ER } & $1^{\text {st }}$ grade & 123 & 5.62 & 1.35 & \multirow{5}{*}{2.990} & \multirow{5}{*}{.019} & \multirow{5}{*}{$1-2.1-4$} \\
\hline & $2^{\text {nd }}$ grade & 131 & 5.04 & 1.76 & & & \\
\hline & $3^{\text {rd }}$ grade & 169 & 5.22 & 1.68 & & & \\
\hline & $4^{\text {th }}$ grade & 96 & 4.96 & 1.85 & & & \\
\hline & $5+$ & 8 & 4.59 & 2.09 & & & \\
\hline \multirow{5}{*}{ Amotivation } & $1^{\text {st }}$ grade & 123 & 2.81 & 1.74 & & & \\
\hline & $2^{\text {nd }}$ grade & 131 & 3.15 & 1.90 & & & \\
\hline & $3^{\text {rd }}$ grade & 169 & 2.70 & 1.75 & & & ---- \\
\hline & $4^{\text {th }}$ grade & 96 & 3.01 & 1.84 & 1.817 & .124 & \\
\hline & $5+$ & 8 & 1.96 & 1.06 & & & \\
\hline & $1^{\text {st }}$ grade & 123 & 4.76 & 1.07 & & & \\
\hline & $2^{\text {nd }}$ grade & 131 & 4.37 & 1.45 & & & \\
\hline Academic Motivation Total & $3^{\text {rd }}$ grade & 169 & 4.57 & 1.30 & 1.701 & .148 & --- \\
\hline & $4^{\text {th }}$ grade & 96 & 4.40 & 1.54 & & & \\
\hline & $5+$ & 8 & 4.24 & 1.50 & & & \\
\hline
\end{tabular}

$* \mathrm{p}>0.05, \mathrm{p}<0.05$.

When the participants' academic motivation scores are examined in terms of grade variable, significant difference was found in the identified extrinsic motivation and extrinsic motivation-external regulation sub-dimensions (IEM and EM-ER). The significant difference was resulted from $1^{\text {st }}$ and $2^{\text {nd }}$ grade students in IEM dimension, and in EM-ER dimension, on the other hand, it was resulted from $1^{\text {st }}$ and $2^{\text {nd }}$ grade students and also $1^{\text {st }}$ and $4^{\text {th }}$ grade students. Difference was not seen in other sub-dimensions. 
Table 8. Anova test results for comparing career stress and their sub-dimensions scores according to grade variable of the participants

\begin{tabular}{|c|c|c|c|c|c|c|c|}
\hline Dimensions & Grade & $\mathrm{N}$ & Ort. & Ss & $\mathrm{F}$ & $\mathrm{P}$ & $\begin{array}{l}\text { Significant } \\
\text { Difference }\end{array}$ \\
\hline \multirow{5}{*}{$\mathrm{Cu}$} & $1^{\text {st }}$ grade & 123 & 2.40 & 1.03 & \multirow{5}{*}{2.848} & \multirow{5}{*}{.023} & \multirow{5}{*}{$1-5$} \\
\hline & $2^{\text {nd }}$ grade & 131 & 2.67 & 1.18 & & & \\
\hline & $3^{\text {rd }}$ grade & 169 & 2.54 & 1.11 & & & \\
\hline & $4^{\text {th }}$ grade & 96 & 2.73 & 1.18 & & & \\
\hline & $5+$ & 8 & 3.52 & 1.00 & & & \\
\hline \multirow{5}{*}{$\mathrm{Jfb}$} & $1^{\text {st }}$ grade & 123 & 2.76 & 1.04 & \multirow{5}{*}{2.549} & \multirow{5}{*}{.039} & \multirow{5}{*}{$1-5$} \\
\hline & $2^{\text {nd }}$ grade & 131 & 2.96 & 1.07 & & & \\
\hline & $3^{\text {rd }}$ grade & 169 & 2.92 & .98 & & & \\
\hline & $4^{\text {th }}$ grade & 96 & 3.06 & 1.06 & & & \\
\hline & $5+$ & 8 & 3.75 & 1.05 & & & \\
\hline \multirow{5}{*}{$\mathrm{Ec}$} & $1^{\text {st }}$ grade & 123 & 2.41 & 1.06 & \multirow{5}{*}{2.001} & \multirow{5}{*}{.093} & \multirow{5}{*}{---} \\
\hline & $2^{\text {nd }}$ grade & 131 & 2.73 & 1.27 & & & \\
\hline & $3^{\text {rd }}$ grade & 169 & 2.53 & 1.14 & & & \\
\hline & $4^{\text {th }}$ grade & 96 & 2.55 & 1.25 & & & \\
\hline & $5+$ & 8 & 3.31 & 1.28 & & & \\
\hline \multirow{5}{*}{ Career Stress Total } & $1^{\text {st }}$ grade & 123 & 2.51 & .96 & \multirow{5}{*}{2.796} & \multirow{5}{*}{.026} & \multirow{5}{*}{$1-5$} \\
\hline & $2^{\text {nd }}$ grade & 131 & 2.77 & 1.10 & & & \\
\hline & $3^{\text {rd }}$ grade & 169 & 2.65 & 1.01 & & & \\
\hline & $4^{\text {th }}$ grade & 96 & 2.79 & 1.08 & & & \\
\hline & $5+$ & 8 & 3.55 & .97 & & & \\
\hline
\end{tabular}

${ }^{*} \mathrm{p}>0.05, \mathrm{p}<0.05$.

When the participants' career stress scores are examined in terms of grade variable, significant difference was found in the career uncertainty (cu), job finding pressure (jfp) and scale total score. There is no difference in extrinsic conflict $(\mathrm{Ec})$ sub-dimension. The difference was resulted from $1^{\text {st }}$ and $5^{\text {th }}$ groups in in the career uncertainty (cu), job finding pressure (jfp) and scale total score.

Table 9. Results of regression analysis for academic motivation and career stress total scores of the participants

\begin{tabular}{lccccc}
\hline Variable & $\mathrm{B}$ & Standard error & $\mathrm{B}$ & $\mathrm{T}$ & $\mathrm{p}$ \\
\hline Constant & 90.361 & 2.730 & & 33.102 & .000 \\
Academic Motivation & -.288 & .021 & -.520 & -13.947 & .000 \\
\hline
\end{tabular}

As a result of simple linear regression, it was found that there is an intermediate negative and significant correlation between academic motivation and career stress. $\left(\mathrm{R}=-52, \mathrm{R}^{2}=.27, \mathrm{p}<.01\right)$. And according to this, academic motivation explains $27 \%$ of total variance in career stress.

\section{Discussion and Conclusion}

In this part of the research, determinations about the correlation between various variables and participants' academic motivation and level of carrier stress were mentioned. Acquired results about the relationship of these parameters with gender, certified sportsmanship, and grade variables were discussed by interpreting.

According to the findings of our research, no significant difference was detected in the participants' academic motivation scores and its sub-dimensions in terms of the gender variable. Studies parallel to our research in terms of their results is encountered in the related literature. Saracaloğlu (2008) and Demir and Arı (2013) state that, in their studies, the participants' academic motivation levels did not differentiate significantly in terms of gender. Our research shows similarity with these studies. There are also studies in the related literature which is different from our study in terms of their findings. Taşkesen et al. (2016) detected that, in their study, averages of female students were higher than the averages of male students in terms of academic motivation and the difference was significant. Also, Aktan (2012), Alemdağ, Öncü, and Yılmaz (2014) mention that average academic motivation scores of female students were higher than male students, in researches made in 2014. These studies differ from our study in terms of their results. Spittle, Jackson and Casey (2009) expressed that the 
higher motivation of female students might be resulted from their high level of engagement during the university years, but they also add that it is only estimation.

The significant difference was not detected in the participants' academic scores and their sub-dimensions according to certified sportsmanship variable. Similar finding is seen in a study made by İlgan et al. (2013). The authors state that it does not affect their level of motivation for the students to have sports licenses or not. This study complies with our study concerning its results. As a result of the research among secondary education students, which was made by Akandere, Özyalvaç, and Duman (2010), it is seen that the students who exercise in their spare time have higher intrinsic motivation scores, that is to say, when the frequency of exercising increases intrinsic motivation scores increases, too. Also the students who never exercise have quite high amotivation scores. When the participants' academic motivation scores are examined in terms of the grade variable, significant difference was observed between the groups in the identified extrinsic motivation and extrinsic motivation extrinsic regulation sub-dimensions. It was seen that the significant difference for identified extrinsic motivation sub-dimension was stemming from the groups 1-2, and for extrinsic motivation extrinsic regulation sub-dimension it was from the groups 1-2, 1-4. There is no significant difference in other dimensions.

Significant differentiation was not seen in the participants' career stress scores and its sub-dimensions in terms of the gender variable. Unlike our findings, when the correlation between gender and career stress was examined in a research made by Üzüm et al. (2018). They state that there is a significant correlation between gender and career uncertainty and lack of knowledge sub-dimension. The authors state that according to this correlation women have more career uncertainty and lack of knowledge than men. The study differentiates from our study in terms of its findings. According to our research findings, significant difference was not detected in the participants' career stress scores and its sub-dimensions in terms of certified sportsmanship variable. In their study, Grove, Lavallee, and Gordon (1997) state that having of a preeminent identity like sportsmanship by sportsman effects their plans about career. But, Bolig (1994) states that many sportsman students don't have a professional career in which the sport field they exercise and thus, they encounter stress related to their need of wondering about their career after school and their academic achievements. But Thompson (1986) states that student athletes' personal, academic and career needs differ from the general student population and points out that the athlete role is independently a source of career stress for the students. Figler and Figler (1984) mentioned career hardships of student athletes through a different point of view. They point out the needs of monitoring the athletes, course selection, evaluating their skill deficits, educational assistance, work environment and their personal and career related advice should be satisfied via investigative consultants.

Significant difference was seen in the participants' career stress scores, career uncertainty, job finding pressure and scale total scores in terms of the grade variable. There is significant difference between $1^{\text {st }}-5^{\text {th }}$ groups in career uncertainty, job finding pressure and scale total scores. It was inferred from our study that the students who are at the graduation level or out-of-course, feel more pressure than the students who newly began to the school in terms of career stress.

Another finding that we obtained as a result of the research is the correlation between increasing academic motivation scores and decreasing career stress. In the analysis made, negative intermediate correlation was detected between two scales. Student athletes, because of their genuine living spaces, should be supported academically and they should be supported with various factors to make plans about their career. Nelson (1983) states that several arrangements should be done in the academic and athletic roles of the students in such cases. Besides, they should be supported with various factors.

In order to provide the academic motivations of the students, it seems extremely important for them to be supported by institutions in which they are educated. In the light of the findings that we obtained from the study results, precautions should be taken in order to support students' career plans and to provide their learning motivation, and this process should be supported.

\section{References}

Akandere, M., Özyalvaç, N. T., \& Duman, S. (2010). Ortaöğretim öğrencilerinin beden eğitimi dersine yönelik tutumları ile akademik baĢarı motivasyonlarının incelenmesi (Konya Anadolu Lisesi Örneği). Selçuk Üniversitesi Sosyal Bilimler Enstitüsü Dergisi, 24, 2-10.

Aktan, S. (2012). Öğrencilerin akademik başarısı, öz düzenleme becerisi, motivas-yonu ve öğretmenlerin öğretim stilleri arasındaki ilişki. Yayınlanmamış dok-tora tezi, Balıkesir Üniversitesi, Balıkesir.

Alemdağ, C., Öncü, E., \&Yılmaz, A. K. (2014). Beden eğitimi öğretmeni adaylarının akademik motivasyon ve akademik öz-yeterlikleri. Spor Bilimleri Dergisi, 25(1), 23-35. 
Bolig, L. A. (1994). Career in Professional Athletics: A Guide for Making the Transition. Colorada Springs, Co: NCAA Publishing.

Bursalığlu, Z. (1999). Okul Yönetiminde Yeni Yapı ve Davranış. Pegem Yayıncılık, Ankara.

Choi, B. Y., Park, H. R., Nam, S. K., Lee, J., \& Lee, S. M. (2011). The development and initial psychometric evaluation of the Korean Career Stress Inventory for college students. Career Development Quarterly, 59, 559-572. https://doi.org/10.1002/j.2161-0045.2011.tb00976.x

Deci, E. L. \& Ryan, R. M. (2000a). The "what" and "why" of goal pursuits: human needs and the self-determination of behavior. Psychological inquiry, 11(4), 227-268. https://doi.org/10.1207/S15327965PLI1104_01

Deci, E. L., \& Ryan, R. M. (2000b). Intrinsic and extrinsic motivations: Classic definitions and new directions. Contemporary Educational Psychology, 25, 54-67. https://doi.org/10.1006/ceps.1999.1020

Demir, M. K, \& Arı, E. (2013). Öğretmen adaylarının akademik güdülenme düzeylerinin çeşitli değişkenler açısından incelenmesi. Eğitimde Kuram ve Uygulama, 9(3), 265-279.

Dörnyei, Z. (1998). Motivation in second and foreign language learning. Language Teaching, 31, 117-135.

Dörnyei, Z., \& Ottó, I. (1998). Motivation in action: A Process Model of L2 Motivation. Working Papers in Applied Linguistics, 4, 43-69. https://doi.org/10.1017/S026144480001315X

Eren, E. (2001). Örgütsel Davranış ve Yönetim Psikolojisi (Genişletilmiş 7. Bask1). İstanbul: Beta Yayınları.

Figler, S., \& Figler, H. (1984). The Athlete's Game Plan for College and Career. Princeton: Peterson's Guides.

Gottfried, A. E. (1990). Academic intrinsic motivation in young elementary school children. Journal of Educational Psychology, 82, 525-538. https://doi.org/10.1037/0022-0663.82.3.525

Grove, J. R., Lavallee, D., \& Gordon, S. (1997). Coping with Retirement from Sport: The İnfluence of Athletic İdentity. Journal of Applied Sport Psychology, 9(2), 191-203. https://doi.org/10.1080/10413209708406481

İlğan, A., Oğuz, E., \& Yapar, B. (2013). Öğrenci Algılarına Göre Okul Yaşam Kalitesi Ve Akademik Motivasyon Düzeyinin Çeşitli Değişkenlere Göre İncelenmesi (Menderes İlçesi Örneği). Abant İzzet Baysal Üniversitesi Eğitim Fakültesi Dergisi.

Işık, E. (2010). Sosyal Bilişsel Kariyer Teorisi temelli bir grup müdahalesinin üniversite öğrencilerinin kariyer kararı yetkinlik ve mesleki sonuç beklenti düzeylerine etkisi. Yayımlanmamış doktora tezi, Çukurova Üniversitesi, Sosyal Bilimler Enstitüsü, Adana.

Karagüven, M. H. (2012). Akademik motivasyon ölçeğinin Türkçeye adaptasyonu. Kuram ve Uygulamada Ĕgitim Bilimleri, 12(4), 2599-2620.

Lunenburg, F., \& Ornstein, A. (2011). Educational administration: Concepts and practices. Nelson Education.

McGrath, J. E. (1970). Social and Psychological Factors in Stress (pp. 14-18). Illinois, Holt Rinehart and Winston Inc.

Nelson, E. S. (1983). How the Myth of the Dumb Jock Becomes Fact: A Developmental View for Counselors. Counseling and Values, 27(3), 176-185. https://doi.org/10.1002/j.2161-007X.1983.tb01131.x

Özden, K., \& Sertel-Berk, Ö. (2016). Üniversite öğrencilerinde psikolojik iyi oluşun psikososyal yordayıcıları, 19. Ulusal Psikoloji Kongresi’nde sunulmuş poster, 5-7 Eylül, İzmir, Türkiye

Özden, K., \& Sertel-Berk, Ö. (2017). Kariyer Stresi Ölçeği'nin (KSÖ). Türkçe’ye Uyarlanması ve Psikometrik Özelliklerinin Sinanması.

Pintrich, P. R., \& Schunk, D. H. (2002). Motivation in education: Theory, research, and applications (2nd ed.). New Jersey: Prentice Hall.

Rivers, W. M. (1983). Speaking in Many Tongues (3rd ed.). New York: Cambridge University Press.

Saracaloğlu, A. S. (2008). Lisanüstü Öğrencilerin Akademik Güdülenme Düzeyleri, Araştırma Kaygıları ve Tutumları ile Araştırma Yeterlikleri Arasındaki İlişki. Yüzüncü Yll Üniversitesi Eğitim Fakültesi Dergisi, 2, 179-208.

Schumarker, R., \& Lomax, R. G. (1996). A beginner's guide to structural equation modeling. Mahwah, NJ; Lawrence Erlbaum.

Spittle, M., Jackson, K., \& Casey, M. (2009). Applying self-determination theory to understand the motivation 
for becoming a physical education teacher. Teaching and Teacher Education, 25(1), 190-197. https://doi.org/10.1016/j.tate.2008.07.005

Taşkesen, O., Yılmaz, M., \& Taşkesen, S. (2016). Güzel Sanatlar Eğitimi Bölümü Öğrencilerinin Bazı Değişkenlere Göre Akademik Motivasyonları ile Akademik Başarıları Arasın-daki İlişkinin İncelenmesi. Erzincan Üniversitesi Ĕ̈itim Fakültesi Dergisi, 18(2), 1056-1072.

Thompson, R. (1986). Improving the Academic Performance of Athletes. NASSP Bulletin, 70(492), 15-19. https://doi.org/10.1177/019263658607049205

Üzüm, B., Uçkun, S., \& Uçkun G. (2018). Üniversite Öğrencilerinin Yaşadığı Bir Fenomen: Kariyer Stresi. Journal of Social and Humanities Sciences Research (JSHSR), 5(24), 1641-1651. https://doi.org/10.26450/jshsr.532

Vallerand, R. J., Pelletier, L. G., Blais, M. R, Brière, N. M., Senécal, C., \& Vallières, E. F. (1992). The academic motivation scale: A measure of intrinsic, extrinsic, and amotivation in education. Educational and Psychological Measurement, 52, 1003-1017. https://doi.org/10.1177/0013164492052004025

Wolters, C. (2004). Advancing achievement goal theory: Using goal structure and goal orientation to predict students' motivation, cognition, and achievement. Journal of Educational Psychology, 96, 236-250. https://doi.org/10.1037/0022-0663.96.2.236

Woolfolk, A. E. (2004). Educational psychology (9th ed.). New York: Pearson.

\section{Copyrights}

Copyright for this article is retained by the author(s), with first publication rights granted to the journal.

This is an open-access article distributed under the terms and conditions of the Creative Commons Attribution license (http://creativecommons.org/licenses/by/4.0/). 